\title{
Gasztroenterológia a nácizmus időszakában
}

\author{
Buzás György Miklós dr.
}

Ferencvárosi Egészségügyi Szolgáltató Nonprofit Kft., Gasztroenterológiai szakrendelés, Budapest

\begin{abstract}
Az orvosi szakirodalomban a nácizmussal a PubMed/ MEDLINE adatbázisban 1845 közlemény foglalkozik (http://www.pubmed.com, 2017. 10. 03.). Kevesebb a merítés akkor, ha azt firtatjuk, milyen hatással volt a nácizmus az egyes szakterületekre: itt egyes területek jól dokumentáltak (például a neuropszichiátria, nőgyógyászat, sterilizálás), másoknak jóval kevesebb figyelmet szenteltek. A közlemény a nemzetközi orvosi irodalom alapján vázolja, hogy mi történt a nácizmus időszaka alatt az emésztőszervek vizsgálata és kezelése területén, kik voltak a történtek áldozatai, elszenvedői, tettesei, mik voltak a következményei, és hogyan hatott mindez a gasztroenterológiára. Ezek az ismeretek hézagosak, különösen a fiatalabb nemzedék számára $[1,2]$. A történtek jelentős befolyást gyakoroltak a későbbi humán orvosi kutatások etikai szemléletére [3]. A téma magyarországi vonatkozásairól egy következő dolgozatban fogok írni: most csupán a nemzetközi adatokra hivatkozom $[4,5]$.
\end{abstract}

\section{A nácizmus ideológiai háttere}

A nácizmus nem Adolf Hitler (1889-1945) hatalomra kerülésével kezdődött: csírái már a 18. század végén megjelentek, a 19. században izmosodtak, s a 20. század elejére már kiteljesedtek: a nácizmus ideológusai eredetit nem találtak ki, csupán egymáshoz illesztették a már meglévő elméletek részleteit. Az 1. táblázatban időrendi sorrendben tekintjük át a nácizmus azon ideológiai előzményeit, amelyek hatással voltak a náci ideológia kialakulására [6-8]: az antiszemitizmus azonban évszázadokkal előbb kezdődött.

\section{A német egészségügy átszervezése a nácizmus idején}

A 19-20. század fordulóján a német orvostudomány vezető szerepet játszott. A Nobel-díjak 50\%-át német tudósoknak ítélték oda [1]. Élen jártak a biokémia, a biofizika, az élettan, a farmakológia, a közegészségügy, a foglalkozási orvostan, de az akkor kialakuló gasztroenterológia területén is. Az oktatás etikai standardját 1900ban fogalmazták meg. Az emberen végzett kutatások etikai követelményeit 1931-ben törvénybe iktatták, rögzítve, hogy kutatás esetén kötelező a beteg tájékoztatása és írásos beleegyezése.

A jól szervezett oktatói és kutatói rendszert „sikerült” néhány éven belül gyökeresen átalakítani. Ebben kulcsszerepe volt Joseph Goebbels (1897-1945) propagandaminiszteren kívül Heinrich Himmlernek (1900-1945), az SS birodalmi vezetőjének, aki nemegyszer a saját ötleteivel járult hozzá az emberkísérletekhez. Amikor megtudta, hogy az SS-katonák a harctéren gyakran vérzésben halnak meg, utasítást adott Sigmund Raschernek (19091945) Dachauban egy olyan szer kidolgozására, amely megelőzi a vérzést [6].

$\mathrm{Az}$ orvostársadalom követte az eugenikai ${ }^{1}$ tevékenységet. A Nemzetiszocialista Orvosligát 1929-ben alapították meg: ennek az akkori orvosok 6\%-a volt a tagja, akik magukévá tették a náci orvosi nézeteket és a zsidóellenességet. Az orvosok 1933 után hamarabb és nagyobb arányban léptek be a náci pártba, mint az értelmiség egyéb rétegei. A náci pártnak 1942-ben 38000 orvos tagja volt, azaz az orvostársadalom fele, akik vallották az északi árja faj felsőbbrendûségét, s elfogadták a fajtisztaság („Rassenhygiene”) elméletét, a „német betegnek német orvost" (deutsche Ärzte für deutsche Kranken) elvét. A propaganda különösen sikeres volt az 1920-30 között végzett fiatal orvosok körében, akiknek a gazdasági válság évei után jobb állást, magasabb fizetést, az egyetemi ranglétrán előrelépést ígértek (például Josef Rudolf Mengelének [1911-1979] minden vágya az egyetemi karrier volt, s azért szegődött el Auschwitzba, mert katedrát ígértek neki) [2]. Ez a törekvés még érthető a feltörekvő fiatal értelmiség részéről, de párosult a német orvostársadalom zsidótlanításával, mivel úgy tartották, hogy a zsidó orvo-

Az eugenika (1. táblázat) a görög $e u=$ jól, helyesen, megfelelően + genes $=$ születés szavakból jött létre. Azokkal a hatásokkal, beavatkozásokkal foglalkozik, amelyek a fajok veleszületett tulajdonságait javítják, tökéletesítik, hogy a legelőnyösebb kialakulásukat elősegítsék. Galton szerint a pozitív eugenika a legkiválóbb adottságú egyének gyermekszámának növelését, a negatív eugenika pedig a genetikai ártalomban szenvedők születéskorlátozását szorgalmazza. A magyar eugenika 1910-1944 között több szakaszban alakult ki, elsősorban Apáthy István (1863-1922) szövettanász-zoológus, Lenhossék Mihály (1863-1937) patológus és Benedek László (1887-1945) ideg-elme gyógyász munkái révén [4]. A téma részletes áttekintése Czeiczel Endre (1935-2015) könyvében olvasható [5]. 
1. táblázat |A nácizmus ideológiájának kialakulása

\begin{tabular}{|c|c|c|c|c|}
\hline Év & Személy & Helység & Mü & Megjegyzés \\
\hline 1798 & $\begin{array}{l}\text { Georges Cuvier } \\
(1769-1832)\end{array}$ & Párizs & $\begin{array}{l}\text { Tableau élémentaire de } \\
\text { l'histoire naturelle des } \\
\text { animaux }\end{array}$ & $\begin{array}{l}\text { Az emberek bőrszínük alapján kaukázusi (fehér), mongol } \\
\text { (sárga) és etióp (barna) fajokra oszthatók. Ádám és Éva kau- } \\
\text { kázusi volt. A kaukázusi emberek a legszebbek, és tulajdonsá- } \\
\text { gaik miatt feljebbvalók a többieknél. }\end{array}$ \\
\hline
\end{tabular}

1798 Thomas Malthus Cambridge An Essay on the Principle A népesség mértani, az élelmiszer-termelés számtani halad(1766-1834) of Population vány szerint növekszik. Megoldás: későn kötött házasság, fogamzásgátlás, önmegtartóztatás, abortusz, illetve háború, természeti katasztrófák. Darwin felhasználta a tanait evolúciós elméletében.

1853-1855 Joseph Arthur Párizs Essai sur l’inégalité des Az emberek árja (eredeti szanszkrit jelentésében nemes, nem-
de Gobineau raceshumaines zetes, később hosszúfejü = dolichocephalus jelzővel kiegé(1816-1882) szült fogalom) és alpin (hegyvidéki, brachycephalus) csoportba oszthatók; keveredésük a fajok degenerációjához vezet. A német az ókori római nép tulajdonságainak örököse.

1859 Charles Robert Cambridge On the Origin of Species by Munkáján 20 évig dolgozott, kimutatva hogy a fajok fejló
Darwin (1809-1882) means of Natural Selection dése a természetes szelekció útján jön létre. Megállapításai azonban az állatvilágra, és korántsem az emberi társadalomra vonatkoztak. Elmélete azóta is megosztja a tudósokat és a teológusokat.

\begin{tabular}{|c|c|c|c|c|}
\hline 1860 & $\begin{array}{l}\text { Ernst Haeckel } \\
(1834-1919)\end{array}$ & Jéna & $\begin{array}{l}\text { „Biogenetikai } \\
\text { alaptörvény” }\end{array}$ & $\begin{array}{l}\text { Darwin németországi népszerúsítése mellett saját fejlődés- } \\
\text { tant dolgozott ki, megfogalmazta az első fajelméletet. A náci } \\
\text { ideológusok idézeteket vettek át munkáiból a rasszista elmé- } \\
\text { letek alátámasztására. }\end{array}$ \\
\hline
\end{tabular}

$1864 \quad$ Herbert Spencer London Principles of Biology A szociáldarwinizmus, azaz Darwin evolúciós elméletének (1820-1903) alkalmazása a társadalomra Spencer munkájából származik, és ez képezte a nemzetiszocialista felfogás alapját. Híres mondására („survival of the fittest”: az erősebb túlélése) előszerettel hivatkoztak a náci ideológusok.

\begin{tabular}{|c|c|c|c|c|}
\hline 1864,1875 & $\begin{array}{l}\text { Francis Galton } \\
(1822-1911)\end{array}$ & London & $\begin{array}{l}\text { Hereditary Genius; } \\
\text { The History of Twins }\end{array}$ & $\begin{array}{l}\text { Angol polihisztor, nevéhez füződik az eugenika fogalmának } \\
\text { bevezetése; nyomában angol, amerikai, francia, svéd, német } \\
\text { és magyar eugenikai társaságok alakultak, némelyiknek jelen- } \\
\text { tôs rasszista elhajlása volt. }\end{array}$ \\
\hline 1899 & $\begin{array}{l}\text { Houston Stewart } \\
\text { Chamberlain } \\
(1855-1927)\end{array}$ & Drezda & $\begin{array}{l}\text { Die Grundlagen des } \\
\text { neunzebnten Jabrhunderts }\end{array}$ & $\begin{array}{l}\text { A francia és az angol kultúrát degeneráltnak tartva, a német } \\
\text { faj felsőbbrendûségét hirdette, a zsidókat alacsonyabb rendü- } \\
\text { nek tartotta. Kulcsszerepe volt a pángermán és az antiszemita } \\
\text { ideológia kialakulásában. }\end{array}$ \\
\hline $1885-1921$ & $\begin{array}{l}\text { Georges Vacher de } \\
\text { Lapouge (1854-1936) }\end{array}$ & Párizs & L'Aryen, son rôle social & $\begin{array}{l}\text { Franciaországban bevezette az eugenikát, hirdette az árja faj } \\
\text { felsóbbrendűségét, amelyet mint „szôke, hosszúfejü” nép- } \\
\text { csoportot határozott meg; a francia Galton Társaság tagja } \\
\text { volt, pályája végén a fasizmussal szimpatizált. }\end{array}$ \\
\hline
\end{tabular}

sok túlreprezentáltak voltak: 1932-ben 52000 orvos közül 6000 volt zsidó (12\%) és továbi 2000 (4\%) zsidó származású, akik elsősorban a nagyvárosokban dolgoztak: Berlinben arányuk 60\% volt. Kiszorításukkal munkahelyek szabadultak fel a fiatal árja orvosok részére $[2,6,7]$.

Egy másik elterjedt módszer volt a zsarolás: Raschert kommunista szimpátiával vádolták, Karl Gebhardt (1897-1948) professzor abban vétkezett, hogy a Reinhard Heydrich (1904-1942), Csehszlovákia akkori helytartója elleni merénylet után nem kezelte a sérültet szulfonamiddal, és gázgangréna alakult ki: Himmler személyesen adott parancsot arra, hogy foglyokon kísérletezze ki a szulfonamidok hatását a gázgangrénára [7]. Bosszúként előbb 10000 cseh kivégzését rendelték el, de ezt bonyolult lett volna megszervezni, így Lidice város 15 év feletti férfilakosságát lőtték agyon.
Nem tudjuk, mikor és hogyan érte el a propaganda, hogy az egyes érintettek emberi mivoltukból kivetkőzve elkövessék tetteiket: erre nem ad választ a nürnbergi orvosper anyaga sem, ahol a vád szakértője Andrew C. Ivy (1893-1978) chicagói fiziológus volt, az amerikai gasztroenterológia prominens alakja, aki később maga is botrányba keveredett egy hatástalan rákellenes szer törvényellenes felhasználása miatt [9].

\section{A nácizmus hatása a gasztroenterológiára}

Az alábbiakban áttekintjük a nácizmusnak a gasztroenterológiára és annak határterületeire kifejtett befolyását, a preklinikai területektől a klinikum felé haladva. A sze- 
replőket részvételük, érintettségük szerint emigránsok, áldozatok, tettesek és kollaboránsok csoportjára osztottuk.

\section{Anatómia}

A náci hatalomátvétel jelentős változásokat hozott a német egyetemek anatómiai intézeteiben: ebben kiemelkedő szerepe volt Eduard Pernkopfnak (1888-1955), aki 1928-tól a bécsi orvosi kar dékánja volt, 1933-tól a náci párt tagja, és egyike azoknak, akik harcoltak a zsidó származású orvosok eltávolításáért az egyetemekről. Számos fórumon hirdette a nácizmus eszméit. Ezerkilencszáznegyvenháromban 7 kötetes anatómiai tankönyvet adott ki, amelyben az ábrákhoz a Gestapo által kivégzett 1377 személy holttestét használta fel: a 800 ábra olyan részletgazdag és pontos volt, hogy a müvet Andreas Vesalius (1514-1564) De humani corporis fabrica címú munkája mellett (amelyet kivégzett bűnözők boncolása alapján írt a szerző) a legjobb tájanatómiai tankönyvnek tartották. Az illusztrációkat három náci múvész készítette, akik az ábrák sarkára horogkeresztet rajzoltak. Az áldozatok neve és a kivégzés időpontja ismert, a legtöbbjük politikai elítélt volt, de akadtak tolvajok, feketézők, prostituáltak is [10]. A könyvnek több kiadása és fordítása van, internetes áruházban angol nyelven ma is kapható, az emésztőszervek anatómiáját tárgyaló 2. kötet ára 154 USD (http://www.amazon.com, 2017. 03. 13.). Pernkopf a számonkérést megúszta, háborús bünökkel sohasem vádolták.

A nácizmus ideje alatt az anatómiai intézetek vezetói szorosan együttmúk ödtek a hatalommal: amint az archívumok elérhetővé váltak, az 1980-as években kiderült, hogy a tübingeni, a bécsi, a kölni, a müncheni, a giesseni, a frankfurti, a heidelbergi, a greifswaldi, a marburgi és a freiburgi egyetemen olyan vezetők kerültek az anatómai intézetek élére, akik engedélyezték és elősegítették az áldozatok boncolását a hozzátartozók beleegyezése nélkül. A nácizmus előtt a holttestek anatómiai-oktatási célra való beszerzése törvényileg szabályozott volt, és mint mindenütt, nehézségekbe ütközött. A diákok száma a numerus clausus miatt 1933 után csökkent, de a szabályok semmibevétele révén a holttestek száma egyre nőtt, a háború idején pedig a halottak szállítása folyamatos és jól szervezett volt. A holttestek a Gestapo, a lágerek áldozataié és hadifoglyokéi voltak. Bár a háború miatt a boncolások nyilvántartása sok helyen elpusztult, néhány intézetben sikerült részben meglelni az áldozatok adatait - például Freiburgban -, de azok nyilvánosságra hozatala kegyeleti okokból korlátozott $[11,12]$.

A lágerekben több olyan anatómus folytatott tevékenységet - Johann Paul Kremer (1883-1965), Hermann Stieve (1886-1952), Otmar von Verschuer (18961969), Hermann Voss (1894-1987), akik elkerülték a felelősségre vonást, és a háború után különböző egyetemeken töltöttek be oktatói/vezető szerepet; egyeseknek szobrot emeltek, másokról tantermet neveztek el [1].
Egyes egyetemeken a nácizmus áldozatainak boncolása és szövettani feldolgozása a háború után is folytatódott: a témát a 2000-es évek óta intenzíven kutatják [12].

\section{Patológia}

A patológusok az anatómusokhoz hasonló szerepet töltöttek be a náci rezsimben: részt vettek az áldozatokból származó anyag vizsgálatában.

Az emigránsok közül említendő Siegfried Oberndorfer (1876-1944), aki 1906-ban írta le a bél karcinoid daganatát; 1911-1933 között a müncheni patológiai intézetben dolgozott, de 1938-ban megfosztották jogaitól, vagyonát elkobozták. Isztambulba emigrált, ahol megalapította a török rákkutató intézetet, és patológiai tankönyvet írt [13].

Nyiszli Miklós (1901-1956), Szilágysomlyón (ma: Şimleu Silvaniei, Románia) született patológus Szaploncáról (ma: a „vidám temetőjéről” híres máramarosi Săpânța, Románia) 1944-ben került Auschwitzba, ahol Mengele boncolóorvosa lett: emlékeirôl a háború utáni egyik első, 1946-ban megjelent beszámolót írta, melynek a fogadtatása vegyes volt: hamisítással, nyerészkedéssel, a történtek elferdítésével vádolták. Könyvében egyetlen gasztroenterológiai leírás olvasható: Mengele munkatársának utasítására több mint 150, hasmenéses betegségben elhunyt fogoly boncolása alapján pontosan leírt olyan elváltozásokat, amelyek megfelelhettek tífusznak, de akár gyulladásos bélbetegségnek is ( 1 . ábra). Több kiadásban - legutóbb 2016-ban - megjelent könyvének [14] megítélése nem mentes a szélsőségektől, a feltétlen méltatástól a holokauszttagadásig.

\section{Biokémia, biofizika}

A nácizmus idején 25 kémikus/biokémikus emigrált Németországból: a legtöbbjük zsidó származású volt, többen a Nobel-díj birtokosai. Távozásuk jelentős érvágás volt a német tudomány számára, amely hanyatlásnak indult, bár néhány jelentős tudós előnyös származása révén megtarthatta vezető pozícióját. Számos emigráns biokémikus tevékenysége kapcsolatban állt a gasztroenterológia akkor aktuális kutatási területeivel $[15,16]$.

\section{Endoszkópia}

Az endoszkópia történetében a nácizmus a félmerev eszközök korszakára esett (1932-g. 1957). A legfontosabb múszaki újítások Németországban és Ausztriában történtek: ez a nácizmus előretörésével megszakadt.

Hermann Strauss (1868-1944) a berlini orvosegyetemet végezte, s kezdetben a gyomorbetegségek radiológiájával foglalkozott. Ezerkilencszáztízben a foovárosi zsidókórház igazgatójává nevezték ki. Ezerkilencszázháromban továbbfejlesztette Howard Kelly (1858-1943) 
Egymás után kerülnek kés alá Obersturmführer dr. Wolff hasmenésben elhalt betegeinek hullái. Már a harmincadik boncolásnál tartok, ősszefoglalom munkám eddigi eredményét. A gyomor nyálkahártyajja minden esetben gyulladásos folyamatot mutat, minek kővetkezménye az emésztônedvet, kủlőnősen a gyomorsósavat kiválasztó mirigyek kiégése, illetőleg teljes sorvadása. Emésztơnedvek hiján nincs emésztés, de annál inkább van erjedés!

Második megfigyelésem eredményeként megállapítom a vékonybél nyálkahártyájának gyulladásos állapotát a bélfalak teljes elvékonyodásával. Harmadik megfigyelésem a vékonybél legiontosabb emésztốnedvére, az epeváladékra vonatkozik, a zsiremésztés nélkülőzhetetlen tényezőjère. Az epehólyag felnyitásánál a sárgászöld epeváladék helyén szintelen, iszapos folyadékot találok, alig festi meg a bélsarat, nem képes emésztési feladatának eleget tenni. Negyedik megfigyelésem a vastagbél nyálkahártyájának gyulladása, a bélfalak teljes sorvadása, megvékonyodása, szakadóssága, akár a cigarettapapír. Nem emésztőcsatornák már ezek, hanem szennycsatornák, amibe ha valamit fent beleöntenek, alól percek alatt távozik. Ezek képezik nagy vonalakban laikusok számára is érthető megállapitásaimat. Nagyon egyhangú, érdekesség nélkülli munka! Ennyi tartozik reám! A bakteriológiai vizsgálatokat valószinũleg a krematóriumoktól két-három kilométerre fekvơ Reisgau ${ }^{191}$ községben felállitott intézet, hivatalos nevén A Fegyveres SS Higiéniai és Bakteriológiai Intézete végzi, ahol egy sorstársam, a nagy hírü Professor dr. Mansfeld, ${ }^{192}$ a pécsi egyetem bakteriológiai intézetének tanára vezeti a munkálatokat.

1. ábra

Részlet $d r$. Nyiszli Miklós könyvéből (Dr. Mengele boncolóor vosa voltam az auschwitzi krematóriumban. Magvető Kiadó, Budapest, 2016, 184. oldal; a kiadó engedélyével)

addig csak rektoszkópiára alkalmas műszerét, így a szigmát is vizsgálni lehetett: Európában a legelterjedtebben használt múszer volt (2. ábra). Kifejlesztette az anoszkópot is. A náci idókben a berlini zsidóság orvosa volt, és ellenállóként tartották számon, ezért 1942-ben Theresienstadtba (ma: Terezín, Csehország) deportálták, ahol 1944-ben öngyilkos lett. Berlinben kórházat neveztek el róla $[17,18]$.

Rudolf Schindlernek (1888-1968) az emigráns szerepe jutott. Schindler 1922-ben módosította a Hans Elsner-féle (1856-1928) merev endoszkópot, de több száz vizsgálat után felismerte annak veszélyeit, és egy német szabadalom alapján hajlékony végú eszközt készített, amelyet a Wolf optikai céggel tökéletesített. Rövidesen több mint 50 tanítvány kereste fel a világ minden részéről. A Gestapo 1933-ban letartóztatta, mert háztartási alkalmazottja feljelentette, hogy egy vacsorai beszélgeté- sen bírálta Hitlert. Részt vett az I. világháborúban, protestáns vallású volt, de a nürnbergi törvények szerint apja miatt félzsidónak számított, így 6 hónapra Dachauba került. Apósa befolyására szabadult, és 1934-ben az Egyesült Államokba távozott, kihasználva, hogy meghívták egy endoszkópos kongresszusra. A chicagói egyetemen helyezkedett el, 1941-ben megalapítottta az Amerikai Gasztroszkópos Klubot (az American Society of Gastrointestinal Endoscopy előfutáraként), s több száz tanítványt fogadott. A német eszközök embargója miatt a félmerev endoszkópot a Cameron és Eder cégek segítségével tökéletesítette: több mint 10000 vizsgálatot végzett. 1943-tól a kaliforniai Loma Linda, 1958-tól a brazíliai Belo Horizonte Minas Gerais egyetemén oktatott $[2,17]$.

Heinrich Lamm (1908-1974) Münchenben volt orvostanhallgató, amikor megfigyelte Schindler félmerev eszközének korlátait, és 1930-ban elsőként sikerült üvegszálon át képet továbbítania. Úgy tervezte, hogy az üvegszálakat beépíti az endoszkópba: erról értesítette Schindlert, de a további kutatáshoz szükséges anyagi forrásokat nem tudta biztosítani. Az egyetem után Boroszlóba (akkor Breslau, ma Wrocław, Lengyelország) ment dolgozni, de 1936-ban megtiltották, hogy árja betegeket kezeljen, $s$ megvonták német állampolgárságát. Feleségével 1937-ben az Egyesült Államokba távozott: elóbb egy texasi, majd egy kaliforniai baptista kórházban dolgozott mint általános sebész. Kutatásaival felhagyott, de 10 német tankönyvet fordított angolra: ez manapság fordítva történik. Megfigyelései 30 évre feledésbe merültek, míg Basil Isaac Hirschowitz (1925-2013) és mtsai szabadalmában az üvegszálak központi szerepet kaptak a képalkotásban (1957) [2, 17].

A nácizmus okozta veszteségek révén az endoszkópia technikai fejlesztésének központja kezdetben Amerikába, majd Japánba került át. Németországban a háború után Georg és Richard Wolf a rektoszkópokat fejlesztette tovább. Az 1945-ben családi vállakozásként alapított KARL STORZ az endoszkópok fejlesztését folytatta [17].

\section{Radiológia}

A röntgensugarak felfedezése német találmány: a röntgendiagnosztika a korát meghazudtoló gyorsasággal terjedt el a világon - így hazánkban is -, s a leglényegesebb fejlesztések német és angol tudósokhoz kötődnek. A német radiológia helyzete a Harmadik Birodalomban az orvostudományok többi ágától eltérő volt, mivel a sterilizációs programban a nácik jelentős szerepet tulajdonítottak a röntgensugarak alkalmazásának. A radiológia helyzetének megítélését nehezítette, hogy a legtöbb intézetvezetô radiológus a háború utolsó éveiben elhunyt, a diszciplína intézményesülése épphogy folyamatban volt, a dokumentáció pedig hiányos maradt $[19,20,21]$. A zsidótlanítás a radiológiában is megvalósult, a terror itt is öngyilkosságokhoz vezetett: például Paul Krause (1871-1934), a belgyógyászati röntgendiagnosztika 


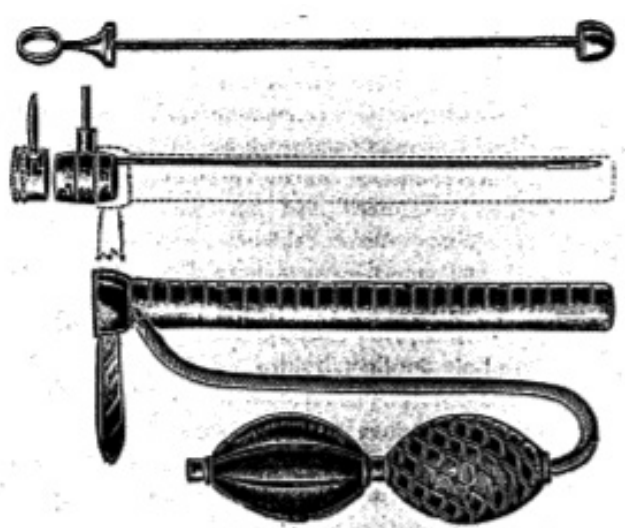

a)

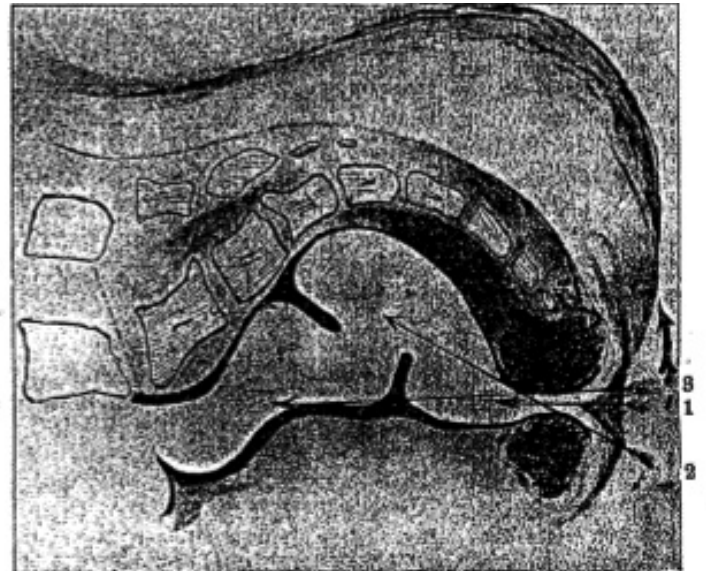

b)

2. ábra

Hermann Strauss által készített rektoszkóp (1903). a) Distalis megvilágítása volt és kettős levegőpumpája. Hossza 15, 25 vagy 35 cm, átmérője 2 cm volt. b) Az eszköz bevezetése (Strauss H. Berl Klin Wochenschr. 1903; 40: 1100-1104)

megszervezője, több szakkönyv szerzője - bár német parasztcsaládból származott - emiatt vetett véget életének: végakaratában tetemét a sugárzás okozta égési sebek tanulmányozására ajánlotta fel [22].

A nácizmus idején a röntgensugaras sterilizáció legálisan engedélyezett volt, sőt egy ideig a háború után is végezték. A sterilizálás egyéb módszereivel szemben ez valószínúleg csekély számban történt, az alanyok száma a hiányos dokumentáció miatt nem is határozható meg pontosan. A dachaui koncentrációs táborban radiológusok és nem radiológusok is végeztek sterilizálást. Auschwitzban „kísérleti” munkát is folytattak: Carl Clauberg (1898-1957) - Mengele szobatársa - a Schering-Kahlbaum-gyár támogatásával új kontrasztanyagot használt, ám ennek összetétele ismeretlen maradt. Egy nőgyógyász terhes anyáknak adott kontrasztanyagot az intrauterin élet vizsgálatára [20]: mindkettőnek Himmler adott utasítást egy gyors módszer kidolgozására a zsidó nők sterilizálása céljából, amit több ezer foglyon el is végeztek. A férfiakat a herék besugárzásával sterilizálták, majd fadarabot vezettek a végbelükbe, és a prosztata masszírozásával próbáltak ondót nyerni a spermiumok vizsgálatára [2].

\section{Klinikai gasztroenterológia}

A gasztroenterológia mint a belgyógyászat önálló ágazata a 19-20. század fordulóján kezdett kialakulni Németországban. Vezető alakja Ismar Isidor Boas (1858-1938) volt. Ô az egyetemet Halléban végezte 1881-ben; 1877-1885 között tesztétellel vizsgálta a gyomorsavtermelést (Boas-féle próbareggeli), 1885-ben Berlinben megalakította az első gasztroenterológiai osztályt, 1890ben megjelentette az első gasztroenterológiai tankönyvet, 1896-ban pedig kiadta az első szakfolyóiratot ( $A r$ chiv der Verdaunngskrankbeiten, ma: Digestion). Ezerkilencszáztizennégyben felismerte az okkult vérzés jelentőségét a gyomorrákban, és megalapította az első szakmai társaságot (Deutsche Gesellschaft für Verdaunngs- und Stoffwechselkrankheiten). Ezerkilencszázharminchatban leváltották, és megtiltották, hogy nem zsidó betegeket kezeljen. Áttelepült Ausztriába, de az 1938. március 12-i Anschluss után öngyilkos lett: nagy adag veronállal vetett véget életének, néhány nappal a 80. születésnapja előtt. Az okkult vérzés kimutatását 1967-ben vezették be, így a vastagbélrák korai felfedezésének lehetősége több évtizedes késésbe került $[23,24]$.

George B. Jerzy Glass (1898-1978) lengyel származású gasztroenterológus volt; 1941-ben távozott Amerikába, miután nagyiparos apósát a nácik megölték. Elsősorban a gyomorsav kutatásával, a $\mathrm{B}_{12}$-vitamin felszívódásával foglalkozott, 4 kötetes tankönyve világszerte népszerú volt $[2,25]$.

\section{Hepatológia}

A nácizmus idején a hepatológia is kezdett önálló tudománnyá válni: ebben a 19-20. századi német patológiai iskolának kiemelkedő szerepe volt.

Abraham Albert Hijmans van den Bergh (1869-1943) holland biokémikus kidolgozta a róla elnevezett reakciót a konjugált és nem konjugált bilirubin kimutatására. A holland "Orvosi Hetilap" (Nederlands Tijdschrift voor Geneeskunde) szerkesztője volt. A Gestapo 1943-ban Utrechtben megölte [2].

A modern hepatológia egyik alapítója a német emigráns Hans Popper (1903-1988). Ó 1928-ban végzett a bécsi orvosegyetemen, majd Hans Eppinger (1. alább) mellett dolgozva kifejlesztette a creatinin clearence meghatározásának egyik korai módszerét. Az Anschluss napján 1938-ban bezárták a rendelőjébe, és letartóztatással fenyegették: kalandos úton az Egyesült Államokba menekült. Az Illinois Egyetemen 1944-ben védte meg doktori értekezését, majd 1948-ban megalapította az első amerikai hepatológiai egyesületet (American Association for the Study of Liver Diseases). Ezerkilencszázötvenhét- 
ben a New York-i Mount Sinai klinika patológusprofeszszora lett, 1958-ban pedig Sheila Sherlockkal (19182001) megalapította a nemzetközi hepatológiai társaságot (International Association for the Study of the Liver). Leírta a májfibrosis patológiáját, a krónikus hepatitis osztályozását, a vinil-klorid okozta májangiosarcomát, a non-A, non-B hepatitis jellegzetességeit. Számos hepatológiai szakkönyv szerzője, szerkesztője. Azok közé tartozik, akiknek a tudományos tevékenysége az emigráció után bontakozott ki [2].

A náci orvosok között a máj nagy érdeklődést keltett. A dachaui koncentrációs táborban 1942-43-ban indikáció és érzéstelenítés nélkül végeztek májbiopsziát a foglyokon: az erről készült szövettani leletek nem maradtak fenn, a vizsgálatok célja nem ismert, és közlemény sem született [2].

Johann Paul Kremer (1883-1965) münsteri anatómus és genetikus 1941-ben lépett be a Wehrmachtba, és 1942-ben néhány hónapot tartózkodott Auschwitzban. Érdeklődött a koplalás hatása iránt, és - saját vallomása szerint - amikor egy soványabb foglyot látott, elrendelte, hogy fenolinjekcióval öljék meg, majd a májból, a lépből és a pancreasból metszeteket készített: elsősorban a máj barna atrófiája érdekelte $[1,2]$. Emellett részt vett a deportáltak szelektálásában és 14 alkalommal a gázkamra múködtetésében, ami több ezer fogoly halálát jelentette. Halálbüntetését életfogytiglanra változtatták, 1958-ban szabadult.

\section{Sebészet}

A német sebészetről ellentmondásos adatok származnak a nácizmus időszakából. Vezető személyisége a korszakban Ernst Ferdinand Sauerbruch (1875-1951) volt, aki Marburgban, Lipcsében tanult, majd Boroszlóban Johann von Mikulicz-Radecki (1850-1903) mellett dolgozott. A berlini Charité klinikán 1927-1949 között a sebészet professzora volt: nevéhez füződik a negatív nyomású lélegeztetőkamra és a múkéz kidolgozása. Már 1923-ban szimpatizált Hitlerrel, és 1933-ból a német rádió archívumából több felvétel került elő, amelyen prominens személyiségek társaságában - például Martin Heidegger filozófussal (1889-1976) - hirdette a nemzetiszocializmus eszméit. Később azonban sokat zaklatták, és magánéletében védte zsidó barátait. Osztályáról csak 3 zsidó munkatársát bocsátotta el. Ugyanakkor, mint a birodalmi kutatási tanács (Reichsforschungsrat) elnöke, támogatta az emberkísérletek terveit. Szolgálatáért évi 2-300 000 márkát fogadott el. Berlin ostroma alatt a klinika bunkerében operált; 1949-ig volt aktív, majd lemondott, és haláláig tiszteletnek örvendve élt a Német Demokratikus Köztársaságban [26].

A nácizmus alatt emigrációba kényszerült sebészek közül kiemelkedik Rudolf Nissen (1896-1981). Részt vett az I. világháborúban, ahol tüdőlövést kapott. A boroszlói egyetemet 1920-ban végezte el. Münchenben Sauerbruch tanítványa volt, majd 1931-ben a berlini Charité klinika sebészeti osztályának vezetője lett. Ő végezte az első tüdőkimetszést (lobectomiát) tuberkulózisban (1930), az első pneumonectomiát tüdótályog miatt (1931) és familiaris polyposisban az első totalis colectomiát ileocaecalis anasztomózissal, ileostoma nélkül. Nem tett azonban eleget 1933-ban annak az utasításnak, hogy a Charité zsidó orvosait elbocsássa. Édesanyja zsidó volt, így a törvény szerint zsidónak számított. Lemondott, és 1933-ban Kemal Atatürk (1881-1938) elnök meghívására az isztambuli egyetem sebészeti tanszékének vezetője lett: itt dolgozta ki a róla elnevezett fundoplicatiót [2, 27]. Babits Mihályt (1883-1941) a pesti zsidókórházban 1938-ban operálta gégerák miatt [28]. A náci befolyás erősödése miatt 1939-ben Amerikába távozott: 1946-ban a paraoesophagealis hernia mütéti megoldását dolgozta ki, 1948-ban pedig Albert Einsteint (1869$1955)$ mütötte hasiaorta-aneurysma miatt. Ezerkilencszázötvenkettőben Svájcba költözött, ahol a bázeli klinikán dolgozott 1967-ig.

Bruno Oskar Pribram (1887-1940) a berlini egyetemen volt sebész: neve az epekőmütét egyik eljárásáról maradt fenn; emellett a fekélybetegség fehérjekezelését vezette be. A nácik 1933-ban leváltották, a háborúban eltünt, életéről további adat nincs [29].

Túlélő lengyel orvosok és más szemtanúk szerint a lágerekben a sebészeti mútéteket rendkívül primitív körülmények között, érzéstelenítés és fertőtlenítés nélkül végezték: a mütött betegek nem részesültek semmiféle posztoperatív ápolásban, gondozásban. Nyiszli szerint azonban voltak Auschwitzban a korabeli körülményeknek megfelelő felszerelésü mütők is, de nem részletezi, ott kik és milyen mútéteket végeztek [14].

\section{Fertőző betegségek}

A fertőző betegségek az emberkísérletek egyik kiemelt témája volt: a nácik a harci sérülésekben fellépett fertőzések ellenszerét keresték. A korabeli orvosok már a napóleoni háborúk idején felismerték, hogy a harctéri veszteségek jó részét a fertőzések okozzák (malária, tífusz, tuberkulózis, sárgaság), ezért a kutatásokat elsősorban e betegségek terén végezték.

Az emberkísérletek a malária vizsgálatával kezdődtek, amelynek vannak hepatológiai vonatkozásai. A maláriaterápia ötlete a bécsi Julius Wagner-Jaureggtől (18571940) származik, aki 1917-ben bevezette hűdéses elmezavarban a harmadnapos maláriakezelést, majd 1921-ben a tabes dorsalist próbálta kezelni Plasmodium vivax inokulációjával: kutatásaiért 1927-ben Nobel-díjat kapott. Meggyőződéses antiszemita és náci volt. Ezerkilencszázhuszonötben Düsseldorf-Grafenbergben, 1926-ban Hamburgban pszichiátriai betegeket kezeltek Plasmodium falciparum adásával, arra számítva, hogy a kialakult lázas állapot enyhíti az elmebetegség tüneteit. Ez a betegek beleegyezése nélkül történt. A kezelés után hepatosplenomegalia keletkezett. Olaszországban 1939-41ben történtek kísérletek maláriaellenes oltóanyag 
kidolgozására, amelyet a Wehrmacht katonáinak szántak. Himmler utasítására a „kutatásokat” áthelyezték Dachauba, ahol Ernst-Robert Grawitz (1899-1945) és Klaus Schilling (1871-1946) vezetésével 1200 cigány foglyot fertőztek meg betegektől származó Plasmodium malariaevel: a fertőző anyag a berlini Robert Koch Intézetből és a Grafenberg Intézetből származott. A betegeknek piramidont, neosalvarsant, aszpirint és a Boehringer cégtôl származó ismeretlen vegyületeket adtak. A kísérleteket a tábor 1945. évi felszabadulásáig folytatták [30].

A tuberkulózist Dachauban és Auschwitzban tanulmányozták: a „kutatásokat” Kurt Heissmeyer (1905-1967) tüdőgyógyász vezette, aki azelőtt a davosi szanatóriumban dolgozott. A célkitűzés ez esetben is egy tbc-ellenes oltóanyag készítése volt. Koch első próbálkozásában 22 orosz foglyot oltott be bacilussal: többségük a fertőzés miliaris disseminatiójában halt meg. Ezt követően Mengele által kiválasztott zsidó gyermekeknek adott tbc-bacilust, az axillaris lymphadenopathiát tanulmányozva. Mivel ellenanyagot találtak, a kísérleti alanyokat kivégezték. Hasonló sorsra jutott az a gyermek- és fogolycsoport, amely 1945 áprilisában érkezett: őket a fertőzés után morfiuminjekcióval ölték meg. Heissmeyer a háború után Magdeburgban folytatta orvosi tevékenységét, de 1963ban életfogytiglanra ítélték: azért nem halálra, mert nem sikerült bizonyítani, hogy ő adott utasítást a gyermekek kivégzésére [30].

A kiütéses tífusz az antibiotikumok előtti érában magas mortalitású járványos betegség volt. A buchenwaldi és a natzweiler-struthofi lágerben 1943-ban Rickettsia prowazekii kórokozókat adtak a foglyoknak - a kísérletek vezetője Eugen Haagen (1898-1972) strassburgi, majd hamburgi virológiaprofesszor volt: az első sorozatban rögtön 29 fogoly halt meg, de sem ebben, sem a következő sorozatokban nem sikerült tífuszellenes antitesteket produkálni. Auschwitzban a Bayer és az IG Farben akridin- és rutenolkészítményeit próbálták ki sikertelenül: a letalitás 53-56\%-os volt, a boncoláskor nephritist, bronchopneumoniát, intestinalis vérzéseket észleltek. A háború után Haagent többször megvádolták és elítélték, de mindig kiszabadult, és 1956-1965 között Tübingenben egy virológiai intézetben, majd Berlinben dolgozott [31].

A gettókban azonban tudományos kutatást is folytattak. A lembergi (ma: Lviv, Ukrajna) gettóban 19411943 között Ludwik Fleck (1896-1961) kidolgozott egy tesztet a kiütéses tífusz ellenanyagának kimutatására vizeletből. Akkoriban a gettó lakosságának 70-100\%-a volt fertőzött, a mortalitás 30\% volt. Ezerkilencszáznegyvenháromban Auschwitzba, onnan Buchenwaldba került, ahol kényszerítették kísérletei folytatására. A lágerben végzett kísérletekról dokumentum nem maradt fenn, de Fleck az Egyesült Államokban megismételte kísérleteit, és közölte eredményeit - ezeket mások is igazolták. Ma már a teszt molekuláris genetikai változatát használják [32].
A fertőzéses sárgaság (akkori nevén icterus epidemicus) is felkeltette az érdeklődést, hiszen a sárgaság is gyakori volt a harctereken. Grawitz vezetésével 1943-ban Sachsenhausenben végeztek kísérleteket halálra ítélt bűnözőkön: az eredményeket Himmlernek jelentette, akinek parancsára Auschwitzból hoztak zsidó gyermekeket és fiatal felnőtteket, és kimutatták, hogy a fertőzés emberről emberre továbbítható. Az oltóanyag kidolgozása sikertelen maradt, és az elhunytak szöveteiból sem sikerült vírust kitenyészteni [31].

Az emberkísérleteket próbálták utólag a tudomány szempontjai szerint értékelni, és kiviláglott a vizsgálati tervek és a módszertani leírások hiánya, az ötletszerű kivitelezés, a dokumentáció és a statisztikai feldolgozás hiányossága, amihez az alanyokkal való bánásmódnak a humánumot teljességgel nélkülöző, a korabeli etikai szabályokat mellőző gyakorlata is társult $[2,6,7]$.

\section{A gyógyszergyárak szerepe}

A német gyógyszercégek készséggel együttmúködtek a nácikkal; 1922-1932 között titkos kutatások folytak fertőtlenítőszerek és maláriaellenes szerek kifejlesztésére. Gerhard Johannes Paul Domagk (1895-1964) 1927-ben került az IG Farbenindustrie-hoz, ahol szerződése szerint sem jövedelméről (10 500 márka), sem kutatásairól nem beszélhetett senkivel. A később Prontosil néven forgalmazott szulfonamidot 1931-1935 között számos vegyület kipróbálása után azonosította [33]. Karl Gebhardt vezetésével „kutatócsoport” alakult: a ravensbrücki lágerben foglyokat fertőztek meg gázgangrénát okozó Clostridiummal, Staphylococcus aureusszal, és a fertőzötteket a Bayer cégtől származó szulfatiazollal vagy szulfacetamiddal kezelték.

Domagk 1939-ben orvosi Nobel-díjat kapott, bár vegyülete nem volt új: azt már 1908-ban szintetizálták, de antibiotikus hatását nem ismerték fel. A Gestapo azonban megakadályozta, hogy a díjat Stockholmban átvegye, és arra kényszerítette, hogy utasítsa vissza a kitüntetést. Ennek oka, hogy Hitler dührohamot kapott, amikor 1935-ben Carl von Ossietzky (1889-1938) pacifista újságíró kapta a Nobel-békedíjat, és ezután a német tudós nem fogadhatta el a magas kitüntetést. Domagk militáns antiszemita lett, magatartását a Reich nagyra értékekelte, és kitüntetéssel jutalmazta. Nobel-díját csak a háború után vehette át [34].

Fontos szerepet játszott az IG Farbenindustrie, amely akkor a világ 4. legnagyobb gyára volt. Az emberen végzett gyógyszerkísérletek fó ideológusa Joachim Mrugowsky (1905-1948) ezredes volt, tôle származik a Zyklon B használata is. Auschwitzban külön mügumigyárat is müködtettek. Ezerkilencszázharminchattól az organofoszfát típusú vegyületekból 2000 fajtát szintetizáltak: ezeket kémiai fegyvernek szánták. Ezerkilencszázharmincnyolcban készült az idegbénító szarin, tabun és szomán: mindhárom előállításában részt vett a vitaminkutatásaiért 1938-ban kémiai Nobel-díjban részesített Richard 
Kuhn (1900-1967). A háború után tonnaszámra égették el a gyár dokumentumait, de néhány vezetőjét halálra vagy életfogytiglani fegyházra ítélték [35].

\section{A holokauszt hosszú távú hatása az emésztőszervekre}

Az élettani kutatások igazolták, hogy a fizikai és a mentális stressz sokrétü hatással van az emésztőszervek mûködésére. Mainzban 1952-ben kimutatták, hogy a volt foglyok májában gyakoriak a disztrófiás elváltozások és a steatosis; 1959-1964 között májbiopsziával igazolták, hogy a krónikus éhezés 24,3\%-ban disztrófiához, további $25 \%$-ban disztrófia és hepatitis megjelenéséhez vezetett (utóbb hasonló eltéréseket találtak a Szovjetunióból hazatérteknél is) [36].

Lipcsei szerzők 1957-1966 között 598, szanatóriumban kezelt túlélőnél 21,5\%-ban találtak májkárosodást (hepatitis, cirrhosis), amelynek mortalitása 3-szor magasabb volt, mint az általános lakosságban; az epebetegségek 5,1\%-a egyezett az átlaggal. Gyomorbetegségek a volt foglyok 30\%-ában léptek fel, a peptikus fekély aránya $8,1 \%$ volt, az átlagosnál lényegesen magasabb. Gyakran észlelték a fekély és a tuberkulózis együttes előfordulását. Az eredmények értékét csökkenti, hogy kontrollcsoport nem volt, illetve nem ismerték a betegek fogság előtti állapotát [37].

Izraeli szerzők 237 túlélő (gettó, koncentrációs tábor, munkatábor) és 384 azonos korú személy emésztőszervi tüneteit kérdő́ivvel mérték fel: a hasi fájdalom, a hasmenés, a székrekedés, a savas regurgitatio, a tenesmus, a hányinger, a hányás és a flatulentia mind a férfiaknál, mind a nőknél szignifikánsan gyakoribb volt a túlélók körében. A panaszok időtartama is sokkal hosszabb volt (15-40 év) a túlélóknél, mint a kontrollcsoportban (5 év) [38].

Az európai származású zsidóknál a daganatos betegségek gyakorisága magasabb, mint a nem európai zsidó és nem zsidó lakosoknál: a 2004-es standardizált adatok szerint a daganatok aránya 278 eset/100 000 beteg/év volt az európai és az amerikai származású zsidó lakosságnál és 224 az ázsiai és afrikai származásúaknál. Egy izraeli munkacsoport az 1960-tól vezetett Izraeli Nemzeti Rákregiszter alapján a háború elótt emigrált 57496 és a háborút túlélt 258048 egyénnél a vastag- és a végbélrák relatív kockázatának jelentős emelkedését észlelte (RR: 1,75, 95\% KT: 1,46-4,06), amely a legkifejezettebb az 1935-1939 között született korcsoportban volt, tehát azoknál, akik gyermekkorban élték túl az eseményeket [39].

Az elszenvedett fizikai és pszichológiai traumák után a Lengyelországból a háború előtt (1939-ig) és 19451950 között kivándorolt 55220 személynél kimutatták, hogy a holokausztot elszenvedő egyének túlélése hoszszabb, mint azoké, akik nem voltak érintettek a háborúban [40]. Az eredményeket az ún. poszttraumás növekedési jelenséggel magyarázzák, amely szerint a fizikai és a mentális stressz, a hiányos táplálkozás és a fertőző betegségek fokozott kockázata miatt a holokauszt idején a gyengébb egyének elpusztultak, míg a túlélók valószínúleg jobb adottságokkal rendelkeztek. A túlélés esélye jelentősebb volt azoknál a férfiaknál, akik serdülő- vagy fiatal férfi korukban élték át az üldöztetést. Mindehhez hozzájárulhatott a háború után a túlélőket övező fokozott családi és társadalmi gondoskodás is [41, 42].

\section{Az eponimákról ${ }^{2}$}

Az orvosi irodalomban is gyakori, hogy egy-egy betegséget, szindrómát, anatómiai struktúrát, élettani/kórélettani jelenséget annak felfedezőjéről/első leírójáról neveznek el. Az eponimáknak vannak pártolóik és ellenzőik, mivel a prioritások gyakran vita tárgyát képezik. Az eponimákban felismerhető́k a náci korszak tettesei és áldozatai.

Hans Eppinger (1879-1946) a vagotonia és a hepatitis kutatásával szerezte hírnevét: 1936-ban Sztálint (18781953), 1937-ben Hohenzollern Mária (1875-1938) román királynét is kezelte. Az egyik leglelkesebb náci orvossá vált, aki 1943-ban a dachaui koncentrációs táborban cigány foglyokat 6-12 napos koplalás mellett tengervízzel itatott a kiszáradás tanulmányozása céljából. A kísérlet letalitása 90\%-os volt. Egy hónappal a nürnbergi orvosperben való tanúskodása előtt, 1946ban méreggel öngyilkos lett. A Falk Alapítvány a róla elnevezett díjat 1973-ban visszavonta, miután fény derült tevékenységére. Nevét a portalis trombózis egyik formája és a póknaevus viseli $[42,43]$.

Friedrich Wegener (1907-1990) neve az általa 1939ben leírt vasculitisról maradt fenn. Már Hitler hatalomra jutása előtt a barnaingesek (Sturmabteilung) tagja lett, majd 1933-ban csatlakozott a náci párthoz, és 1938-ban alezredesi rangot kapott. A łódźi gettóba 1939-ben került mint patológus, ahol a kivégzett foglyok boncolását végezte, de sohasem ítélték el. A nevét viselő betegséget ma polyangitisszel járó granulomatosisnak vagy antinukleáris antitestasszociált vasculitisnek nevezik. A betegség 10-50\%-ban gastrointestinalis manifesztációkkal jár (bélinfarktus, haemorrhagiás colitis, peritonitis, akut hasi kórképek), amelyek 56-100\%-os letalitást okoznak. A fóbb légzőszervi szakmai társaságok 2012-ben úgy döntöttek, hogy törlik a nevét az eponimákból: ez csak részben valósult meg $[44,45]$.

${ }^{2}$ Az eponima valamely személyről, helységről vagy jelenségről született elnevezés. Az asszírok a Kr. e. 2. évezredben magas rangú vezetőikről nevezték el az éveket. A görögök is jeles vezetőikről neveztek el korszakokat (például Szolón, Periklész), a Bibliában Izrael 12 törzsét Jákob fiairól/unokáiról nevezték el. Angliában egyes történelmi időszakokat uralkodókról (például Erzsébet-kori, viktoriánus), Amerikában elnökökról (például Nixon-éra) neveztek el. A politikában vezérekról (hitlerizmus, sztálinizmus, maoizmus) neveztek el mozgalmakat. A tudományban az eponima valamely felfedező nevét viseli, egyben jelezve annak szellemi tulajdonát. Az érdeklődőknek az elnevezés magyarázata megtalálható a szótárakban (Merriam-Webster, Dorland, Oxford, Larousse) és az interneten is. 
Pólya Jenó (1876-1944) a magyar hasi sebészet egyik vezető alakja. Miután Dollinger Gyula (1849-1937) munkatársa volt, Herczel Manó (1862-1918) meghívására a Szent István Kórház sebészeti osztályára került: itt dolgozta ki 1910-11-ben a Billroth II. mütét módosítását, amely Amerikában Pólya-, Európában Reichel-Pólya-mútét néven vált ismertté, olyannyira, hogy a mai tankönyvekben is szerepel. Jelentôs munkája Az orvostudomány regénye című 1942. évi könyve, amelyben tényleg regényes formában foglalja össze az orvoslás történetét [46]. Budapest ostroma alatt, 1944 decemberében a nyilasok fóbe lőtték és a Dunába dobták: tetemét sohasem találták meg $[2,36]$.

Ludwig Pick (1868-1944) német patológus Lipcsében tanult, majd egy magánklinikán dolgozott; 1906-tól a berlini Friedrichshain klinika patológusa lett. Számos hozzájárulása közül említendő a hepatosplenomegaliával járó, Albert Niemann-nal (1880-1921) leírt sphyngomyelinosis, a koleszterin felszívódásában szerepet játszó Niemann-Pick Cl-protein, a Lubarsch-Pick-szindróma (macroglossia, amyloidosis) és a Pick-sejtnek nevezett histiocyta. Bár harcolt az I. világháborúban, származása miatt a theresienstadti lágerbe került, ahol 1944. február 3-án elhunyt [42, 47].

Egy tudós tevékenységének magas rangú elismerése, ha nevét adják a felfedezéséhez. Az eponimák nem örök életúek: az utókor etikai kötelessége, hogy a névadók munkáját felülvizsgálja, és törölje azoknak a nevét, akiknek a múködését emberellenes tevékenység árnyékolja be. Múveik, még ha tudományos jelentőséggel bírnak is, csak úgy idézhetők, ha említésre kerül bűnös múltjuk is. $\mathrm{Az}$ áldozatok nevét nemcsak idézni kell, de méltatásuk mellett oktatni kellene tevékenységük történelmi hátterét és körülményeit is [37]. Enélkül a történtek feledésbe merülnek, s amit elfelejtenek, utóbb máshol, más köntösben megismétlődhet.

Anyagi támogatás: A közlemény megírása anyagi támogatásban nem részesült.

A cikk végleges változatát a szerző elolvasta és jóváhagyta.

Érdekeltségek: A szerzőnek nincsenek érdekeltségei.

\section{Köszönetnyilvánítás}

Az irodalomkutatást Szilágyi Anna (Semmelweis Egyetem, Élettani Intézet), a szövegszerkesztést Józan Jolán végezte: munkájukat köszönet illeti.

\section{Irodalom}

[1] Cohen MM Jr. Overview of German, Nazi and Holocaust medicine. Am J Med Genet. 2010; 152(A3): 687-707.

[2] Cappell MS. The effect of Nazism on medical progress in gastroenterology. Dig Dis Sci. 2006; 51: 1137-1156.
[3] Kerpel-Fronius S. The epoch-changing influence of the Nuremberg doctor's trial on the ethical judgment of human experiments. [A nürnbergi orvosper korszakváltó befolyása a humán kísérletek etikai megítélésére.] Orv Hetil. 2008; 149: 195-201. [Hungarian]

[4] Eugenics in Hungary. [Eugenika Magyarországon.] Available from: http://www.hu.wikipedia.org.wiki/Eugenika/Eugenika [accessed: October 12, 2017]. [Hungarian]

[5] Czeiczel E. Human genetics. [Az emberi öröklődés.] Gondolat Kiadó, Budapest, 1983; pp. 227-231. [Hungarian]

[6] Garver KL, Garver B. Eugenics: past, present, and the future. Am J Hum Genet. 1991; 49: 1109-1118.

[7] Leo A. Medical science under dictatorship. N Engl J Med. 1949; 241: 39-47.

[8] Barondess JA. Medicine against society. Lessons from the Third Reich. JAMA 1996; 276: 1657-1661.

[9] Krebiozen. Available from: http://en.wikipedia.org/wiki/Krebiozen [accessed: March 6, 2017].

[10] Israel HA, Seidelman WE. An anatomy text: the Pernkopf atlas. JAMA 1996; 276: 1633-1637.

[11] Hildebrandt S. Insights into the Freiburg Anatomical Institute during National Socialism, 1933-1945. Ann Anat. 2016; 205: 90-102.

[12] Oehler-Klein S, Preuss D, Roelcke V. The use of executed Nazi victims in anatomy: findings from the Institute of Anatomy at Giessen University, pre- and post-1945. Ann Anat. 2012; 194: 293-297.

[13] Modlin IM, Shapiro MD, Kidd M. Siegfried Oberndorfer: origins and perspectives of carcinoid tumors. Human Pathol. 2004; 35: 1440-1451.

[14] Nyiszli M. I was Dr. Mengele's pathologist in Auschwitz crematory. [Dr. Mengele boncolóorvosa voltam az auschwitzi krematóriumban.] Magvető Kiadó, Budapest, 2016; pp. 184-195. [Hungarian]

[15] Deichmann U. Chemists and biochemists during the National Socialist era. Angew Chem Int Ed Engl. 2002; 41: 1310-1328.

[16] Nachmansohn D. German-Jewish pioneers in science: physics, chemistry, and biochemistry. Springer Verlag, Berlin, 1979.

[17] Villardel F. Digestive endoscopy in the second millennium. Thieme Verlag, Stuttgart, 2006; pp. 59-78.

[18] Strauss H. On the method of rectoscopy. [Zur Methodik der Rectoskopie.] Berl Klin Wochenschr. 1903; 40: 1100-1104. [German]

[19] Schmidt M, Winzen T, Gross D. The German Radiological Society and the Protagonists of Radiology during the Time of National Socialism - State of Research, Explanation Attempts, Desiderata and Research Prospects. [Die Deutsche Röntgengesellschaft und die Protagonisten der Radiologie in der Zeit des Nationalsozialismus - Forschungsstand, Erklärungsansätze, Desiderate und Perspektiven.] Fortschr Röntgenstr. 2015; 187: 425-429.

[20] Moser G. Radiology in the Nazi era: part 1. The state, citizens, and marginalization: normality in the Nazi state. Strahlenther Onkol. 2014; 190: 502-513.

[21] Moser G. Radiology in the Nazi era: part 3. Roentgen studies and national health: radiology and roentgenology in the Nazi eugenics policy. Strahlenther Onkol. 2014; 190: 607-620.

[22] Ferdinand U, Kirchner J. Prof. Dr. med. Paul Krause (18711934) - Pioneer of X-ray diagnosis and an early victim of the National Socialist regime. [Geheimrat Prof. Dr. med. Paul Krause (1871-1934) - Pionier der Röntgendiagnostik und frühes Opfer des nationalsozialistischen Regimes.] Fortsch Röntgenstr. 2015; 181: 817-820. [German]

[23] Hansen WE. Memory of Ismar Boas (1858-1938). [Erinnerung an Ismar Boas (1858-1938.) Z Gastroenterol. 2013; 51: 378380. [German]

[24] Teichmann W. Ismar Boas (1858-1938). Falk Foundation, Freiburg, 1992. 
[25] Glass GB. Progress in Gastroenterology. Vols. I-IV. Grune \& Stratton, New York-London, 1968-1983.

[26] Dewey M, Schagen U, Eckart WU, et al. Ernst Ferdinand Sauerbruch and his ambiguous role in the period of national socialism. Ann Surg. 2006; 244: 315-321.

[27] Gillison W, Elder JB. The changing tides in oesophageal surgery. In: Gillison WE, Buchwald H. (eds.) Pioneers in surgical gastroenterology. TFM Publishers Ltd, Harley, 2017; pp. 37-64.

[28] Szállási Â. Diseases of Mihály Babits (1883-1941). [Babits Mihály (1883-1941) betegségei.] Magyar Tudománytörténeti Intézet, Budapest. é. n. [Hungarian]

[29] Pribram BO. Progress in Pathology and Surgical Treatment of Gallstones. [Fortschritte in der Erkenntnis der Pathologie und der chirurgischen Behandlung des Gallensteinleidens.] Gustav Fischer Verlag, Jena, 1930. [German]

[30] Sabbatani S. The infectious diseases experiments conducted on human guinea pigs by Nazis in concentration camps. [Gli esperimenti di infezioni su cavie umane compiuti dai nazisti nei campi di concentramento.] Infez Med. 2013; 2: 151-166. [Italian]

[31] Weisz GM, Grzybowski A. Medical discoveries in the ghettos: the anti-typhus battle. Isr Med Assoc J. 2011; 13: 261-265.

[32] Fleck L. Specific antigenic substances in the urine of typhus patients. Texas Rep Biol Med. 1947; 5: 168-172.

[33] Domagk G. Contribution to the treatment of bacterial infections. [Ein Beitrag zur Chemotherapie der bakteriellen Infektionen.] Dtsch Med Wochenschr. 1935; 61: 250-253. [German]

[34] Lesch JE. The first miracle drugs. How sulfa drugs transformed medicine. Chapter 6. Pathways of Recognition. Oxford University Press, Oxford, 2007; pp. 122-157.

[35] López-Muñoz F, García-García P, Alamo C. The pharmaceutical industry and the German National Socalist Regime: I.G. Farben and pharmacological research. J Clin Pharm Ther. 2009; 34: 67-77.

[36] Gros H. Dystrophy and late liver damages. [Dystrophie und Leberspätschäden.] Munch Med Wochenschr. 1964; 106: 891896. [German]
[37] Böhme H, Scharkoff T, Scharkoff H. Late consequences of ab normal living conditions. [Spätschäden nach abnormen Lebensbedingungen.] Z Altersforsch. 1969; 22: 55-68. [German]

[38] Stermer E, Baer H, Levy MD. Chronic functional gastrointestinal symptoms in Holocaust survivors. Am J Gastroenterol. 1991; 86: 417-422.

[39] Binan-Boker L, Vin-Raviv N, Lipshitz I, et al. Cancer incidence in Israeli Jewish survivors of World War II. J Natl Cancer Inst. 2009; 101: 1489-1500.

[40] Bercovich E, Keinan-Boker L, Shasha SM. Long-term health effects in adults born during the Holocaust. Isr Med Assoc J. 2014; 16: 203-207.

[41] Sagi-Schwartz A, Bakermans-Kranenburg MJ, Linn S, et al. Against all odds: genocidal trauma is associated with longer lifeexpectancy of the survivors. PLoS One 2013; 8: e69179.

[42] Strous RD, Edelman MC. Eponyms and the Nazi era: time to remember and time for change. Isr Med Assoc J. 2007; 9: 207214.

[43] Spiro HM. Eppinger of Vienna: scientist and villain? J Clin Gastroenterol. 1984; 6: 493-497.

[44] Gea J, Orozco-Levi M, Aguiló R. Wegener's disease and Clara cells: eponyms and dignity in respiratory medicine. Arch Bronconeumol. 2013; 49: 126-127. [Article in Spanish]

[45] Pagnoux C, Mahr A, Cohen P, et al. Presentation and outcome of gastrointestinal involvement in systemic necroziting vasculitides. Medicine 2005; 84: 115-128.

[46] Pólya J. The Story of Medicine. [Az orvostudomány regénye.] Béta Irodalmi Rt., Budapest, 1941. [Hungarian]

[47] Ludwig Pick. Available from: http://www.whonamedit.com/ doctor.cfm/1023.html [accessed: October 13, 2017].

(Buzás György Miklós dr., Budapest, Mester u. 45., 1095 e-mail: drbgym@gmail.com)

\title{
ME GHÍl ó
}

\section{A Szent János Kórház és Észak-budai Egyesített Kórházak Tudományos Bizottsága tisztelettel meghívja az érdeklődőket a következő tudományos ülésére.}

\author{
Időpont: 2018. január 25. (csütörtök) 14.00 óra
}

\section{Helyszín: Szent János Kórház Auditóriuma - 1125 Budapest, Diós árok 1-3. \\ Téma: A rehabilitációs tevékenység aktuális helyzete kórházunkban}

Üléselnök: Dr. Jánosi András

\section{Program:}

Dr. Medveczky Erika: Paradigmaváltás a gyermekkori izomdystrophiak intervenciójában

20 perc

Dr. Farkas Edina: Gyermekpszichiátriai rehabilitációt igénylö állapotok

10 perc

Rosta Nóra: Pszichoterápiás szemlélet a gyermek- és ifjúságpszichiátriai rehabilitációban

10 perc

Dr. Trócsányi Márta: Minden nap két lépéssel többet

20 perc

\section{Minden érdeklődőt szeretettel várunk!}

